Volume 10 Issue 2, April-June 2016: pp. 221-412. Copyright (C) 2015-2016 FIAT JUSTISIA. Faculty of Law, Lampung University, Bandarlampung, Lampung, Indonesia.

ISSN: 1978-5186 | e-ISSN: 2477-6238.

Open Access: http://jurnal.fh.unila.ac.id/index.php/fiat

Fiat Justisia is licensed under a Creative Commons Attribution 4.0 International License, which permits unrestricted use, distribution, and reproduction in any medium, provided the original work is properly cited.

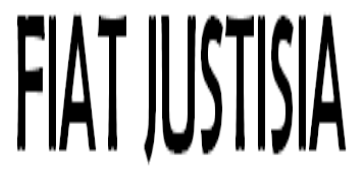

\title{
STUDI KOMPARATIF PENGATURAN SISTEM PEMILIHAN UMUM ANGGOTA DEWAN PERWAKILAN RAKYAT DI INDONESIA
}

\section{Comparative Study Regulation of Electoral System of the House of Representatives in Indonesia}

\author{
Agus Effendi \\ Pengadilan Tata Usaha Negara Medan \\ email: aguseffendi_9@yahoo.com
}

\begin{abstract}
Electoral system is one of the factors that affect the development of democracy and political state. It is need to get the attention of people who want improvement democracy. The electoral system, especially in implementation of house of representative election, it becomes a study that need attention given during the general election of house of representative (DPR) members eleven times from some period of democracy is different, it cannot fully realize the elections are truly ideal for the development of democracy and resulted in the representatives of the people and reflecting the aspirations properly represent the people's interests. Electoral Systems Member house of representative applied to the Election Period Old Order Period until Election Reform Order, both the closed proportional system and open proportional system and the rest of the votes, in principle have a weakness at the same advantages.
\end{abstract}

Keywords: Regulation, Election System, House of Representative

\begin{abstract}
Abstrak
Sistem pemilu sebagai salah satu faktor yang mempengaruhi perkembangan demokrasi dan politik negara, tentunya sangat perlu untuk mendapat perhatian dari kita semua yang menginginkan perbaikan demokrasi. Sistem pemilu, khususnya dalam penyelenggaraan pemilu anggota DPR, menjadi kajian yang perlu mendapat perhatian mengingat selama penyelenggaraan pemilihan umum anggota DPR sebanyak 11 (sebelas) kali dari beberapa
\end{abstract}


masa demokrasi yang berbeda-beda, belum sepenuhnya dapat mewujudkan pemilu yang benar-benar ideal bagi perkembangan demokrasi dan menghasilkan wakil-wakil rakyat yang aspiratif dan benar-benar mewakili kepentingan rakyat. Sistem Pemilihan Umum Anggota DPR yang diterapkan pada Pemilu Masa Orde Lama sampai dengan Pemilu Masa Orde Reformasi, baik sistem proporsional tertutup maupun sistem proporsional terbuka dan sisa suara terbanyak, pada prinsipnya memiliki kelemahan sekaligus kelebihan.

Kata Kunci: Pengaturan, Sistem Pemilihan Umum, Dewan Perwakilan Rakyat

\section{A. Pendahuluan}

Pemilihan umum merupakan kebutuhan mutlak bagi setiap negara modern dalam rangka menegakkan dan mempertahankan sistem demokrasi. ${ }^{1}$ Pemilihan umum menjadi agenda penting karena sebenarnya pemilihan umum merupakan salah satu cara pelaksanaan demokrasi, khususnya bagi demokrasi perwakilan. Di negara modern, demokrasi langsung sudah tidak berlaku, yang berlaku adalah demokrasi perwakilan atau demokrasi tidak langsung. ${ }^{2}$ Demokrasi perwakilan ini tentunya membutuhkan orang-orang yang akan mewakili masyarakat untuk menentukan haluan atau kebijakankebijakan yang berkaitan dengan kepentingan seluruh masyarakat. Dalam keadaan yang demikian, pemilihan umum memegang peranan penting dalam negara demokrasi, yaitu berfungsi sebagai alat penyaring bagi orang-orang yang akan mewakili dan membawa suara rakyat di dalam lembaga perwakilan. ${ }^{3}$ Dengan demikian pemilihan umum mempunyai hubungan erat dengan demokrasi.

Indonesia sebagai salah satu negara hukum penganut paham demokrasi, tentunya juga menempatkan pemilihan umum sebagai agenda penting yang harus dilaksanakan. Oleh karena itu, pemilihan umum diatur dalam konstitusi kita, yaitu dalam Pasal 22E Undang-Undang Dasar 1945 (Amandemen III). Pengaturan pemilihan umum sebagai lembaga tersendiri dalam konstitusi, mengisyaratkan bahwa pelaksanaan pemilihan umum yang bebas dan dilakukan secara periodik menjadi sebuah keniscayaan di negara Indonesia.

\footnotetext{
${ }^{1}$ Samego, Indria, dkk. (1998). Menata Negara Usulan LIPI Tentang RUU Politik Bandung: Mizan, p. 37.

${ }^{2}$ Mahfud MD, Moh. (1999). Hukum dan Pilar-Pilar Demokrasi. Yogyakarta: Gama Media, p. 220.

${ }^{3}$ Ibid., p. 220-221.
} 
Gambaran Indonesia sebagai negara yang menganut paham demokrasi, secara eksplisit telah dicantumkan dalam Pasal 1 ayat (2) Undang-Undang Dasar 1945 (sebelum amandemen) yang menyatakan kedaulatan berada di tangan rakyat dan dilakukan sepenuhnya oleh Majelis Permusyawaratan Rakyat (MPR). ${ }^{4}$ Dengan demikian, kedaulatan tertinggi berada di tangan rakyat, yang pelaksanaannya diserahkan kepada MPR. Namun dalam perjalanannya, lembaga MPR yang dianggap sebagai representasi dari rakyat telah mengalami berbagai macam penyimpangan dan hanya dijadikan alat legitimasi bagi pemerintah atau penguasa untuk mempertahankan kekuasaannya. Melalui Amandemen ketiga UndangUndang Dasar 1945, dilakukan perubahan tentang pelaksanaan kedaulatan rakyat yang tidak lagi dijalankan hanya oleh MPR, tetapi pelaksanaan kedaulatan rakyat dilaksanakan menurut Undang-Undang Dasar ${ }^{5}$. Dilakukannya perubahan ini, MPR tidak lagi memiliki kedudukan yang eksklusif sebagai satu-satunya lembaga pelaksana kedaulatan rakyat, karana di samping MPR ada pula lembaga-lembaga negara lain yang juga merupakan pelaksana kedaulatan rakyat, misalnya Presiden yang dipilih secara langsung oleh rakyat. ${ }^{6}$

Selain berhubungan erat dengan demokrasi, pemilihan umum juga berhubungan erat dengan prinsip negara hukum. Melalui pemilihan umum, rakyat atau masyarakat dapat memilih wakil-wakilnya yang berhak membuat produk hukum dan melakukan pengawasan atau pelaksanaan kehendakkehendak rakyat yang digariskan oleh wakil-wakil rakyat tersebut. Jika dikaitkan dengan prinsip dasar dalam negara hukum, pemilu mempunyai hubungan erat dengan prinsip perlindungan terhadap hak-hak asasi manusia, persamaan di depan hukum dan pemerintahan, serta adanya pemilu yang bebas. Melalui pemilihan umum, maka hak asasi rakyat yang salah satunya adalah hak politik dapat disalurkan. Hak untuk diperlakukan sama di depan hukum dan pemerintahan juga mendapatkan salurannya. Begitu pula dengan adanya pemilu yang bebas, maka penyaluran hak demokratis atau hak politik rakyat dapat mencapai tujuannya. Dengan demikian pemilu merupakan cara untuk merealisasikan prinsip negara hukum. ${ }^{7}$

Secara tegas, gambaran bahwa Indonesia negara hukum dicantumkan dalam naskah Amandemen Ketiga Undang-Undang Dasar 1945 Pasal 1 ayat (3) yang berbunyi, "Negara Indonesia adalah Negara hukum". Dengan demikiaian Indonesia bukanlah negara kekuasaan atau machsstaat dimana

\footnotetext{
${ }^{4}$ Lihat naskah UUD 1945 sebelum Amandemen Pasal 1 ayat (2).

${ }^{5}$ Lihat naskah Amandemen Ketiga UUD 1945 Pasal 1 ayat (2).

${ }^{6}$ Asshidiqie, Jimly. (2002). Konsolidasi Naskah UUD 1945 Setelah Perubahan Keempat, Jakarta: Pusat Studi HTN FH-UI, p. 2. Untuk pemilihan Presiden Langsung, lihat naskah Amandemen Ketiga UUD 1945 Pasal 6A.

${ }^{7}$ Mahfud MD, Moh. Op.Cit. p. 221-222.
} 
aturan negara ditentukan oleh penguasa negara dan diperuntukkan untuk mempertahankan kekuasaannya. Mengenai konsepsi negara hukum yang dianutnya, Indonesia menganut konsepsi campuran dari konsepsi Rechstaat dan Rule of Law. ${ }^{8}$

Pada dasarnya, antara negara demokrasi dan negara hukum ibarat dua sisi dari dari satu mata uang. Tidak akan tercipta sebuah negara demokrasi tanpa ditopang oleh penegakan hukum, dan sebaliknya hukum tidak akan tegak tanpa ditopang oleh kelangsungan kehidupan politik yang demokratis. ${ }^{9}$ Dengan demikian hukum dan demokrasi akan berjalan secara bersamaan dan berbanding lurus. Semakin demokratis kehidupan politik negara, maka hukum yang diciptakan akan mencerminkan aspirasi masyarakat sehingga penegakan hukum akan terwujud.

Prasyarat yang harus dipenuhi untuk menciptakan kehidupan politik yang demokratis dan terealisasinya prinsip negara hukum bagi negara adalah terwujudnya lembaga-lembaga negara ${ }^{10}$ yang benar-benar memperoleh legitimasi rakyat sebagai perwujudan dari kedaulatan rakyat. Legitimasi rakyat menjadi syarat mutlak bagi pemerintahan untuk melaksanakan pemerintahannya mengingat dalam Undang-Undang Dasar 1945 sebagai konstitusi kita, dinyatakan kedaulatan berada di tangan rakyat yang pelaksanaannya didasarkan kepada Undang-Undang Dasar, dan berdasarkan UUD 1945 (setelah Amandemen), secara eksplisit kedaulatan rakyat dilaksanakan oleh Presiden sebagai perwakilan eksekutif, DPR sebagai perwakilan politik dan DPD sebagai perwakilan daerah. ${ }^{11}$ Untuk memperoleh legitimasi rakyat, idealnya ketiga perwakilan itu dipilih secara langsung oleh rakyat melalui pemilihan umum, bukan melalui proses pengangkatan oleh pemerintah, seperti yang pernah terjadi di masa orde baru. Bagaimanapun juga hampir tak ada pemerintah yang bisa bekerja secara bertanggung jawab tanpa dukungan dan kepercayaan rakyat yang diberikan melalui pemilihan umum. ${ }^{12}$

Tidak adanya lagi wakil rakyat yang diangkat oleh pemerintah, diharapkan tidak terjadi lagi adanya lembaga perwakilan yang hanya menjadi alat dari pemerintah (eksekutif) untuk mempertahankan kekuasaannya. Dan sebaliknya diharapkan akan muncul wakil-wakil rakyat

${ }^{8}$ Ibid., p. 138.

${ }^{9}$ Ibid, p. 176.

${ }^{10}$ Lembaga-lembaga yang dimaksudkan adalah lembaga legislatif dan lembaga eksekutif sebagai bagian dari empat pilar demokrasi selain yudikatif dan pers. Mengenai empat pilar demokrasi, dapat dilihat dalam Ibid, p. 2.

11 Asshiddiqie, Jimly. (2003). "Hubungan Kerja Antara DPD Dengan Lembaga Negara Lainnya". Makalah disampaikan dalam rangka "Focus Group Discussion" yang diselenggarakan oleh Set-Jen MPR bekerjasama dengan Universitas Brawijaya di Malang pada tanggal 27 Maret 2003, p. 1.

${ }^{12}$ Samego, Indria. dkk, Op. Cit., p. 37. 
yang berpihak kepada kepentingan rakyat dan akan memperjuangkan apa yang menjadi aspirasi dari rakyat, sesuai dengan apa yang telah menjadi harapan kita bersama demi menegakkan demokrasi dan supremasi hukum di Indonesia.

Indonesia negara yang menjunjung tinggi demokrasi dan mengedepankan prinsip negara hukum, dalam penyelenggaraan negaranya, pemilihan umum yang bebas dan dilakukan secara periodik telah menjadi agenda negara yang mutlak harus dilaksanakan. Pemilihan umum adalah lembaga demokrasi untuk mengaktualisasikan aspirasi dan kepentingan rakyat yang menjadi perwujudan kedaulatan rakyat. ${ }^{13}$ Hal ini sejalan dengan apa yang ditetapkan International Comission of Jurists pada konferensinya di Bangkok, 1965 yang salah satu isinya menyatakan bahwa adanya pemilihan umum yang bebas merupakan salah satu kriteria dari negara hukum yang dinamis. ${ }^{14}$

Selama Indonesia merdeka, tercatat telah sebelas kali Indonesia melakukan pemilihan umum untuk memilih wakilnya yang duduk di lembaga Legislatif, yaitu mulai dari Pemilu Tahun 1955 sampai dengan Pemilu 2014. Dari sebelas kali penyelenggaraan itu, delapan pemilihan umum yang dilangsungkan hanya untuk memilih wakil-wakil rakyat yang duduk di DPR, yaitu Pemilu Tahun 1955 sampai dengan Pemilu 1999. Namun setelah dilakukan Amandemen Ketiga UUD 1945, maka pemilihan umum tidak hanya dilakukan untuk memilih anggota DPR saja, tetapi juga untuk memilih anggota DPR, DPD, dan DPRD, serta Presiden dan Wakil Presiden. ${ }^{15}$

Pemilihan umum pertama dilakukan tahun 1955 pada suatu masa demokrasi parlementer (antara tahun 1945-1959) yang diselenggarakan dalam dua tahap, yang pertama pada bulan September 1955 untuk memilih anggota DPR dan bulan Desember 1955 untuk memilih Anggota Konstituante. ${ }^{16}$ Pemilu selanjutnya baru dapat terlaksana pada di masa pemerintahanSoeharto (orde baru) pada tahun 1971 untuk memilih anggota DPR dan DPRD, namun penyelenggaraannya dianggap tidak demokratis mengingat adanya kecenderungan dari pemerintah yang memihak kepada salah satu peserta pemilu, yaitu Golongan Karya sehingga memunculkan partai-partai politik yang mulai mengalami kemunduran atau mendekati masa surutnya. ${ }^{17}$

\footnotetext{
${ }^{13}$ Ibid, p. 39.

${ }^{14}$ Mahfud MD, Moh. Op. Cit., p. 131.

${ }^{15}$ Lihat naskah Amandemen Ketiga UUD 1945 Pasal 22E ayat 2.

${ }^{16}$ Lihat sejarah pemilu yang dimiliki oleh KPU. Diperoleh melalui website www.kpu.go.id.

${ }^{17}$ Dhakidae, Daniel. (1981). "Pemilihan Umum Di Indonesia: Saksi Pasang Naik dan Surut Partai Politik", majalah Prisma edisi September 1981 Tahun X, Jakarta: LP3ES.
} 
Selama masa orde baru, pemilihan umum telah dilakukan selama enam kali, mulai dari pemilu 1971, dilanjutkan dengan pemilu 1977, 1982, 1987, 1992 dan 1997. Selama itu hampir semuanya direkayasa sehingga menghasilkan pemenang mutlak yang sama, yaitu Golongan Karya, yang menyebabkan Golkar menjadi partai hegemonik ${ }^{18}$ dan telah menjadi alat politik untuk mempertahankan kekuasaan. Pada masa itu Pemilu tak lebih menjadi alat legitimasi bagi rezim politik orde baru untuk melestarikan status quo otoritarianisme politik. ${ }^{19}$ Praktis selama orde baru pemilu tidak didasarkan pada ide demokrasi, sementara dengan pemilu demokratislah yang akan membawa angin segar pengharapan akan tatanan politik baru yang mencerminkan aspirasi dari rakyat yang berdaulat. ${ }^{20}$

Setelah masa orde baru berakhir, pada tahun 1999 di masa Pemerintahan Transisi Presiden B.J. Habibie diselenggarakan pemilihan umum dengan jumlah peserta sebanyak 48 partai politik, dimana pemilu tersebut menjadi gerbang menuju orde reformasi. Pemilihan umum berikutnya diselenggarakan pada tahun 2004, dimana pada pemilihan umum tersebut tidak saja memilih Anggota DPR, tetapi juga sudah memilih anggota DPD, dan pada masa itu juga dilakukan Pemilihan Presiden dan wakil Presiden secara langsung untuk pertama kalinya. Dilanjutkan pada masa Pemerintahan Presiden Susilo Bambang Yudhoyono (SBY), pemilihan umum anggota DPR diselenggarakan dua kali yaitu pada pemilihan umum tahun 2009 dan terakhir pada pemilihan umum tahun 2014.

Pada dasarnya demokratis tidaknya suatu penyelenggaraan pemilu ditentukan oleh beberapa unsur, yang salah satunya yaitu sistem pemilu. ${ }^{21}$ Sistem pemilu memegang peranan penting mengingat pilihan terhadap sistem pemilu ini akan berdampak terhadap sistem kepartaian yang ada yang berarti berdampak luas pula pada kehidupan politik dan demokrasi di negara Indonesia. Sistem pemilu juga memegang peranan yang penting dalam menentukan sukses tidaknya pemilu sebagai sarana partisipasi aktif rakyat Indonesia, khususnya dalam membangun Indonesia menjadi bangsa yang demokratis dan berkedaulatan rakyat.

Sistem pemilu sebagai salah satu faktor yang mempengaruhi perkembangan demokrasi dan politik negara, tentunya sangat perlu untuk mendapat perhatian dari kita semua yang menginginkan perbaikan demokrasi. Sistem pemilu, khususnya dalam penyelenggaraan pemilu anggota DPR, menjadi kajian yang perlu mendapat perhatian mengingat

18 Gaffar, Afan. (2000). Politik Indonesia Transisi Menuju Demokrasi, Cetakan II. Yogyakarta: Pustaka Pelajar, p. 33.

${ }^{19}$ Samego, Indria. dkk. Op. Cit., p. 38 dan 40.

${ }^{20}$ Sutrisno Dermawan, Bernad. (2002). Konflik Politik Di KPU Dalam Pemilu 1999. Jakarta: PT. Mutiara Sumber Widya, p. iv.

${ }^{21}$ Ibid., p. x. 
selama penyelenggaraan pemilihan umum anggota DPR sebanyak 11 (sebelas) kali dari beberapa masa demokrasi yang berbeda-beda, belum sepenuhnya dapat mewujudkan pemilu yang benar-benar ideal bagi perkembangan demokrasi dan menghasilkan wakil-wakil rakyat yang aspiratif dan benar-benar mewakili kepentingan rakyat.

Melalui pengkajian sistem-sistem pemilihan umum anggota DPR dan memperbandingkan antara masing-masing sistem pemilu yang telah diterapkan dalam masa-masa atau orde pemerintahan yang berbeda-beda di Indonesia, maka akan diketahui persamaan ataupun perbedaan dari masingmasing sistem pemilu, yang dalam hal ini dengan menggunakan beberapa variabel sistem pemilihan sabagai alat perbandingan yang akan diuraikan pada bagian pembahasan nantinya. Dengan menganalisa perbandingan tersebut, maka akan diketahui juga nilai kelebihan (positive values) ataupun nilai kekurangan (negative values) dari setiap sistem pemilu tersebut, yang pada akhirnya kita dapat mempersiapkan sistem pemilihan umum yang baik atau setidak-tidaknya secara temporer tepat untuk diterapkan pada penyelenggaraan pemilihan umum anggota DPR yang akan datang.

Kajian mengenai sistem pemilihan umum, khususnya pemilihan umum anggota dewan perwakilan rakyat telah dilakukan oleh banyak kalangan, termasuk para akademisi. Di antara yang paling terkenal adalah Miriam Budiardjo seorang Guru Besar Ilmu Politik, dan juga Mahfud MD seorang Guru Besar Hukum Tata Negara. Miriam Budiardjo dengan karyanya yang sangat populer yaitu "Dasar-Dasar Ilmu Politik" mengkaji pemilihan umum ataupun sistem pemilihan umum dari kajian ilmu politik dan cenderung hanya menjadikan pemilihan umum sebagai variabel atau bagian kecil dalam mempelajari ilmu politik. Begitu juga Mahfud MD dalam bukunya berjudul "Politik Hukum Di Indonesia"2 hanya mengkaji hukum pemilihan umum sebagai wujud dari karakter produk hukum pada masa perkembangan demokrasi di Indonesia. Mereka tidak sampai atau belum sampai mengkaji secara khusus mengenai sistem pemilihan umum anggota DPR yang pernah diatur dan diterapkan pada pemilihan umum di Indonesia, termasuk juga belum sampai melakukan komparasi atau perbandingan antara

\footnotetext{
${ }^{1}$ Buku ini adalah karya Miriam Budiardjo yang sudah beberapa kali diterbitkan oleh PT Gramedia Pustaka Utama dan terakhir kali diterbitkan sebagai Edisi Revisi Cetakan kesembilan, Oktober 2013. Dalam buku tersebut ilmu politik didefinisikan sebagai ilmu yang mempelajari politics atau kepolitikan, dan politik diartikan sebagai usaha menggapai kehidupan yang baik.

${ }^{2}$ Buku ini adalah karya Moh. Mahfud MD, pernah diterbitkan oleh LP3ES dan terakhir oleh PT RajaGrafindo Persada sebagai Edisi Revisi Cetakan ke-5, November 2012. Dalam bukunya tersebut hukum pemilu menjadi salah satu kajian dari karakter produk hukum selain hukum pemda dan hukum agraria.
} 
sistem-sistem pemilihan umum yang digunakan pada periode-periode pemilu yang berbeda dari beberapa masa atau orde pemerintahan di Indonesia.

Berdasarkan uraian di atas, maka melalui tulisan ini akan dibahas atau dikaji mengenai pengaturan dan perbandingan sistem pemilihan umum anggota dewan perwakilan rakyat yang diterapkan pada beberapa pemilihan umum di Indonesia, mulai dari Pemilu pada masa Orde Lama sampai dengan Pemilu pada masa Orde Reformasi sekarang ini. Oleh karena itu, tulisan ini diberikan judul : "Studi Komparatif Pengaturan Sistem Pemilihan Umum Anggota Dewan Perwakilan Rakyat Di Indonesia".

Permasalahan atau isu yang diangkat dalam tulisan ini yaitu :pertama, Bagaimanakah perbandingan pengaturan sistem pemilihan umum Anggota Dewan Perwakilan Rakyat di Indonesia. Kedua, Apa saja kelemahan dan kelebihan dari sistem pemilihan umum Anggota Dewan Perwakilan Rakyat di Indonesia. Kemudian metode penelitian menggunakan metode normatif yuridis.

\section{B. Pembahasan}

\section{Pengertian Sistem Pemilihan dan Model Sistem Pemilihan}

Sistem pemilihan adalah seperangkat metode yang mengatur warga negara memilih para wakilnya. Dalam suatu lembaga perwakilan rakyat, seperti lembaga legislatif atau DPR/DPRD, sistem pemilihan ini bisa berupa seperangkat metode untuk mentransfer suara pemilih ke dalam suatu kursi di lembaga legislatif atau parlemen. Namun, ketika pemilihan itu terjadi pada seorang kepala pemerintahan sebagai representasi tunggal seperti Presiden, Gubernur, Bupati dan semacamnya (DPD termasuk di dalamnya), sistem pemilihan itu bisa berwujud seperangkat metode untuk menentukan seorang pemenang berdasarkan jumlah suara yang diperolehnya. Dalam bahasa yang sederhana, sistem pemilihan ini pada dasarnya berkaitan dengan cara pemberian suara, penghitungan suara, dan pembagian kursi. ${ }^{3}$

Andrew Reynolds dalam seminar dan lokakarya bertema "Toward Structural Reforms on Democratization in Indonesia : Problem and Prospects" di Jakarta, 11-14 Agustus 1998, memberikan pengertian bahwa sistem pemilu adalah sarana rakyat yang merupakan institusi yang digunakan untuk menyeleksi para pengambil keputusan ketika masyarakat telah menjadi terlalu besar bagi setiap warga negara untuk ikut terlibat dalam setiap pengambilan keputusan yang mempengaruhi komunitas. Sistem pemilu adalah metode yang di dalamnya suara-suara yang diperoleh dalam

\footnotetext{
${ }^{3}$ Asfar Muhamad (Editor). (2002). Model-Model Sistem Pemilihan Di Indonesia. Surabaya: Pusat Studi Demokrasi dan HAM dan Partnership for Governance Reform in Indonesia, p. 9-10.
} 
pemiluhan diterjemahkan menjadi kursi-kursi yang dimenangkan dalam parlemen oleh partai-partai dan para kandidat. ${ }^{4}$

Benjuino Theodore juga memberikan pengertian tentang sistem pemilu. Ia berpendapat bahwa sistem pemilihan umum adalah rangkaian aturan yang menurutnya : (1) pemilih mengekspresikan preferensi politik mereka, dan (2) suara dari para pemilih diterjemahkan menjadi kursi. Definisi ini mengisyaratkan bahwa sistem pemilu mengandung elemenelemen struktur kertas suara dan cara pemberian suara, besar distrik, serta penerjemahan suara menjadi kursi. Dengan demikian hal-hal seperti administrasi pemilihan umum dan hak pilih, walaupun penting, berada di luar lingkup pembahasan sistem pemilihan umum. ${ }^{5}$

Sistem pemilihan merupakan sesuatu yang sangat penting dalam kehidupan sebuah negara mengingat sistem pemilu mempunyai akibat yang sangat luas dalam menentukan bentuk pemerintahan, sistem kepartaian, sistem politik dan lain sebagainya. Berkaitan dengan sistem pemilihan ini, Afan Gaffar memberikan pendapatnya mengenai beberapa hal yang sangat perlu mendapat perhatian dalam sistem pemilihan ${ }^{6}$. Pertama adalah apa yang disebut sebagai "electoral formula", yaitu apakah akan menggunakan sisitem pluralitas (distrik), ataukah sistem proportional representation dengan berbagai macam variasinya. Elektoral formula menentukan alokasi kursi yang akan diberikan kepada masing-masing partai atau peserta yang bersaing. Kedua adalah menyangkut "district magnitude", yaitu jumlah wakil rakyat yang dipilih dalam sebuah daerah pemilihan atau distrik. Besar sebuah distrik dapat berbeda satu sama lain karena jumlah perbedaan penduduk. Besaran kursi yang diperebutkan bagi sebuah distrik (district magnitude) merupakan sesuatu yang sangat penting dikarenakan akan menentukan nasib partai-partai politik di kemudian hari. Semakin besar magnitude sebuah distrik, akan semakin besar kesempatan partai kecil untuk memperoleh kursi, sebaliknya kalau district magnitude-nya kecil, maka partai yang memperoleh suara relatif sedikit dari total suara, tidak akan memiliki peluang untuk memperoleh kursi. Ketiga adalah menyangkut apa yang disebut sebagai "electoral threshold", yaitu jumlah minimum suara yang harus diperoleh oleh seseorang atau sebuah partai untuk memperoleh kursi di lembaga perwakilan.

\footnotetext{
${ }^{4}$ Bhakti, Ikrar Nusa dan Sihbudi, Riza (Editor). (2001). Menjauhi Demokrasi Kaum Penjahat. Bandung: Mizan, p. 102.

5 Theodore, Benjuino. (2003). Sistem Pemilihan Umum: Sebuah Perkenalan, dalam Pemilu Indonesia Online, Mei 2003.

${ }^{6}$ Gaffar, Afan. Op.Cit., p. 25-26.
} 
Selain ketiga hal di atas, Muhamad Asfar juga menambahkan beberapa hal lain yang juga perlu untuk mendapatkan perhatian berkaitan dengan sistem pemilu ini. ${ }^{7}$ Hal-hal lain itu adalah :

a. Struktur pemilihan, yaitu apakah seseorang pemilih dapat memilih lebih dari satu partai politik atau kandidat dalam suatu pemilihan umum yang sama atau tidak;

b. Malapportionment, yaitu suatu bentuk disproporsionalitas dalam suatu sistem pemilihan, yang bisa berupa overrepresentative atau underrepresentative;

c. Garrymandering, yaitu suatu mekanisme untuk menentukan batas-batas distrik, yang dalam prosesnya biasanya sering terjadi para partisan garrymandaring memanipulasi batas-batas distrik untuk keuntungan partai politik yang disukainya;

d. Apparentement, yaitu suatu hubungan formal dari daftar partai yang diijinkan di dalam suatu sistem daftar, yang umumnya berlaku pada negara yang mendapatkan formula pemilihan perwakilan berimbang, seperti seseorang hanya boleh memilih satu partai, dua partai atau sebanyak yang disukainya;

e. Ukuran Badan Perwakilan Rakyat, yaitu jumlah atau kuota kursi yang diperebutkan atau tersedia dalam suatu daerah pemilihan;

f. Hal lain atau dimensi lain yang berkaitan dengan proses penyelenggaraan pemilu, seperti yang berkaitan dengan hak pilih (siapa yang mempunyai hak pilih), persyaratan pendaftaran (didaftar atau mendaftarkan diri, dan apa syaratnya), akses terhadap tempat pemungutan suara (apakah sulit atau mudah), prosedur nominasi (apakah dilakukan secara internal partai atau melibatkan pemilih), dan sebagainya.

Pendapat yang hampir sama juga dikemukakan oleh Arend Lijphart yang pada prinsipnya menyatakan bahwa ada tujuh variabel atau atribut yang terkait dengan sistem pemilihan, yaitu : electoral formula, district magnitude, electoral threshold, the total membership of the body to be elected, the influence of presidential elections on legislative elections, malapportionment, dan interparty electoral links. ${ }^{8}$

Secara garis besar, sistem pemilu hanya terkait dua hal, yaitu mengenai mekanisme pemilihannya (electoral process) dan mengenai sistem/metode pemilihannya (electoral laws) ${ }^{9}$, dan dari kedua hal tersebut dikaitkan dengan uraian-uraian yang diberikan oleh Afan Gaffar, Muhammad Asfar maupun Arend Lijphart itu, kita dapat mengetahui bahwa

\footnotetext{
${ }^{7}$ Asfar, Muhammad (Editor), Op. Cit., p. 13-14.

${ }^{8}$ Lijphart, Arend. (1999). Patterns of Democracy, USA: Yale University Press, p. 144-146.

${ }^{9}$ Tentang electoral laws dan electoral process, lihat Gaffar, Afan. (1989). "Sistem Pemilihan Umum di Indonesia: Beberapa Catatan Kritis", dalam Majalah Unisia Edisi No. 6 Th. X Triwulan III, p. 14.
} 
tidak semua hal tentang pemilu merupakan unsur atau bagian dari kajian sistem pemilu, hanya beberapa hal yang menjadi kajian dari sistem pemilu dikaitkan dengan electoral laws dan electoral process, diantaranya adalah : electoral formula, district magnitudo, electoral threshold, struktur pemilihan (kertas suara), Malapportionment, Garrymandering, Apparentement, Ukuran Badan Perwakilan Rakyat, dan Interparty Electoral Links.

Terkait dengan model sistem pemilihan, berdasarkan sejarah pelaksanaan pemilihan umum di berbagai negara, maka terdapat tiga macam sistem pemilu (electoral laws), yaitu sistem mayoritas (majority types), sistem pluralitas (plurality types) yang biasa disebut sistem distrik, dan sistem perwakilan berimbang (proportional representation). ${ }^{10}$ Dalam sistem mayoritas, partai yang menang dalam pemilu adalah partai yang mampu mengalahkan semua partai lawan-lawannya. Sedangkan dalam sistem pluralitas, pemenang pemilu adalah partai yang memperoleh suara yang relatif lebih besar dari partai-partai lain tanpa harus mengalahkan secara mutlak melalui pemenangan atas kombinasi partai-partai lawan. Dalam sistem pluralitas (distrik) ini wilayah negara dibagi atas sejumlah distrik (sesuai dengan jumlah kursi yang diperebutkan) dan kursi pada setiap distrik diambil oleh partai atau calon yang memperoleh suara terbanyak di distrik tersebut.

Dalam pemilu dengan sistem perwakilan berimbang memungkinkan terjadinya distribusi suara secara proporsional sehingga partai yang memperoleh suara terbanyak akan memperoleh kursi yang lebih banyak pula, sedangkan partai yang tidak memperoleh suara terbanyak tidak akan kehilangan suara yang diperoleh karena tetap akan memperoleh kursi seimbang dengan besarnya jumlah suara yang diperolehnya. Dalam sistem proporsional setiap kursi diberi harga dengan jumlah suara tertentu.

Arend Lijphart dalam bukunya yang berjudul "Patterns of Democracy" (1999), secara garis besar membagi sistem pemilihan ke dalam dua kelompok sistem, yaitu menggabungkan sistem majority dengan sistem plurality dalam satu kelompok sistem pemilihan, dan sistem proportional representation sebagai sistem pemilihan lainnya. ${ }^{11}$

Prof. Miriam Budiardjo secara umum membedakan sistem pemilihan menjadi dua prinsip pokok ${ }^{12}$, yaitu : Single-member constituency (satu daerah pemilihan memilih satu wakil, biasanya disebut Sistem Distrk), dan Multi-member Constituency (satu daerah pemilihan memilih beberapa wakil,

\footnotetext{
${ }^{10}$ MD. Moh. Mahfud, Hukum dan Pilar..., Op. Cit., p. 223-226.

${ }^{11}$ Lihat Lijphart, Arend. Op. Cit., p. 143.

12 Budiardjo, Miriam. (2013). Dasar-Dasar Ilmu Politik, Edisi Revisi Cetakan kesembilan. Jakarta: PT Gramedia Pustaka Utama, p. 177-180.
} 
biasanya dinamakan Proportional Representation atau Sistem Perwakilan Berimbang).

Baik sistem perwakilan berimbang (proportional representation) ataupun sistem distrik, masing-masing mempunyai beberapa variasi. Sistem perwakilan berimbang mempunyai variasi antara lain ${ }^{13}$ :

a. PR dengan sistem daftar tertutup (closed list system); Dalam sistem ini pemilih hanya boleh memilih partai, bukan calon yang bertarung.

b. PR dengan sistem daftar terbuka (open list system); Dalam sistem ini pemilih tidak hanya memilih partai, tetapi juga memilih calon yang dikehendakinya. Pemilih dapat memilih satu atau lebih dari satu calon.

c. The Single Transferable Vote (STV), disebut juga sebagai sistem QuotaPreferenial atau Hare-Clark System; Dalam sistem ini tidak ada suara yang terbuang sia-sia, karena suara yang berlebih pada seorang calon dapat ditransfer kepada calon yang lain.

d. The Single Non-Transferable Vote (SNTV); Sistem ini tidak memberikan peluang untuk mentransfer suara dari satu calon ke calon lain dalam partai yang sama.

e. PR dengan sistem sisa suara terbanyak atau The Largest Remainder.

f. Sistem rata-rata tertinggi atau The Highest Avarage; dalam sistem ini, rata-rata diperoleh dari pembagian jumlah suara pada sebuah distrik, dengan jumlah kursi ditambah satu.

Dan sistem distrik mempunyai variasi antara lain ${ }^{14}$ :

a. Absolute Majority, yaitu sebuah sistem distrik di mana calon yang memperoleh suara 50\% ditambah satu $(50 \%+1)$ yang akan memenangkan distrik pemilihan tersebut.

b. Simple Majority, yaitu sebuah sistem distrik dimana calon yang memeperoleh suara relatif terbanyak dibandingkan calon lain, sekalipun kurang dari 50\%, maka calon tersebut akan memenangkan pemilihan di distrik itu.

c. Gabungan antara keduanya, dimana pemilihan dilakukan dalam dua tahap apabila ditahap pertama tidak ada calon yang memperoleh suara lebih dari 50\%. Tahap pertama digunakan simple majority, dan apabila tidak ada yang meraih suara lebih dari 50\%, maka kemudian diambil dua calon peraih suara terbanyak untuk dipilih kembali pada pilihan tahap kedua (run-off election). Dalam tahap kedua ini hanya ada dua calon yang akan dipilih sehingga pemenangnya mutlak meraih suara lebh dari 50\%. Yang digunakan pada tahap kedua adalah sistem absolute majority.

${ }^{13}$ Gaffar, Afan. Politik Indonesia ..., Op. Cit., p. 261-265.

${ }^{14}$ Ibid., p. 265-266. 


\section{Perbandingan Pengaturan Sistem Pemilu Anggota DPR di Indonesia}

Perbandingan atau komparasi pengaturan sistem pemilu anggota DPR ini didasarakan pada masing-masing pengaturan peraturan perundangundangannya. Pada prinsipnya antara Pemilu yang satu dengan Pemilu lainnya pada Masa Orde Lama, Masa Orde Baru dan Masa Orde Reformasi, memiliki beberapa persamaan sekaligus memiliki beberapa perbedaan berkaitan dengan pengaturan unsur atau variabel sistem pemilihan anggota DPR yang digunakan.

Secara umum persamaan antara sistem pemilu pada pemilu-pemilu tersebut adalah persamaan dalam hal penerapan pengaturan sistem pemilihannya yang menggunakan sistem proporsional atau perwakilan berimbang sebagai sistem induknya, sementara perbedaan-perbedaan yang muncul lebih banyak mengenai perbedaan pengaturan unsur atau variabel sistem yang merupakan variasi dari sistem induknya. Sebagai gambaran, dalam Pemilu Masa Orde Lama pada Pemilu 1955 mengatur dan menerapkan sistem proporsional atau perwakilan berimbang dikaitkan dengan variasi sistem daftar (terbuka) atau open list system dan sisa suara terbanyak. Kemudian dalam Pemilu Masa Orde Baru mengatur dan menerapkan sistem proporsional dikaitkan dengan variasi sistem stelsel daftar atau daftar calon tertutup (closed list system) dengan sedikit unsur sistem distrik, dan pada Pemilu Masa Orde Reformasi, pernah mengatur dan menerapkan kedua jenis sistem proporsional baik sistem proporsional tertutup pada Pemilu 1999 maupun sistem proporsional terbuka dan sisa suara terbanyak pada Pemilu 2004 sampai dengan Pemilu 2014.

Lebih jelas tentang perbandingan pengaturan sistem pemilihan Anggota DPR di Indonesia, selanjutnya akan dibahas mengenai persamaan dan perbedaan sistem pemilihan umum dalam Pemilu Masa Orde Lama pada Pemilu 1955 sampai dengan Pemilu Masa Orde Reformasi, didasarkan pada beberapa parameter perbandingannya. Parameter tersebut secara garis besar dikelompokkan dalam dua kategori, yaitu unsur atau variabel yang termasuk dalam kategori proses/mekanisme pemilihan (electoral process), dan unsur atau variabel yang termasuk dalam kategori sistem/metode pemilihan (electoral laws). ${ }^{15}$ Unsur electoral process diantaranya yaitu : daerah pemilihan, jumlah kursi, peserta, pencalonan dan penyusunan daftar calon, struktur pemilihan (struktur surat suara), cara pemberian suara, dan cara penghitungan suara, sementara unsur electoral laws yang terpenting di

15 Electoral Process adalah mekanisme yang dijalankan dalam pemilu seperti pencalonan, cara penghitungan suara, penentuan hasil, dan sebagainya. Electoral laws adalah sistem pemilihan dan perangkat peraturan yang menata bagaimana pemilu dijalankan serta bagaimana distribusi hasil pemilu itu. Lihat MD, Moh. Mahfud, Politik Hukum..., Op. Cit. p. 74, lihat juga Gaffar, Afan. Sistem ..., Op. Cit. p. 14. 
antaranya yaitu : tata cara pembagian kursi, tata cara penetapan calon terpilih, dan ada tidaknya penggabungan suara.

\section{Persamaan}

Sejak Pemilu Masa Orde Lama hingga Pemilu Masa Orde Reformasi, tidak semuanya mengatur dan menerapakan sistem pemilu dengan variasi dan proses pemilihan yang sama. Namun demikian, pada beberapa penyelenggaraan Pemilu tersebut, ada persamaan-persamaan berkaitan dengan hal-hal atau parameter-parameter tertentu terkait sistem pemilihan yang digunakan, baik untuk semua pelaksanaan Pemilu maupun untuk beberapa pelekasanaan Pemilu. Secara garis besar, unsur atau variabel sistem pemilihan yang sama pada setiap sistem pemilihan anggota DPR sejak Pemilu Masa Orde Lama sampai dengan Pemilu Masa Orde Reformasi berkaitan dengan :

a. Cara penetapan jumlah kursi untuk setiap daerah pemilihan, dimana salah satu cara penetapannya menggunakan dasar perimbangan jumlah penduduk pada setiap daerah pemilihan;

b. Model sistem pemilihan atau electoral laws, dimana semua Pemilu menggunakan sistem proporsional atau perwakilan berimbang;

c. Cara pemberian suara untuk tanda gambar parpol atau daftar, persamaan terjadi pada semua Pemilu, yaitu dengan cara menusuk atau mencoblos tanda gambar peserta, kecuali pada Pemilu 2009 dengan cara memberi tanda.

d. Sahnya suara, semua Pemilu mulai Pemilu1955 hingga Pemilu 2014 menyatakan suara tetap sah walaupun pemilih hanya memilih parpol atau daftar saja dan tidak memilih nama calon.

e. Cara penetapan kuota atau harga sebuah kursi, pada dasarnya, semua Pemilu menetapkan suatu kuota atau harga sebuah kursi untuk setiap daerah pemilihan dengan cara membagi jumlah sah seluruh suara masuk dari semua partai dengan jumlah kursi yang tersedia dalam suatu daerah pemilihan.

f. Cara pembagian kursi tahap pertama, semua Pemilu menerapkan cara pembagian yang sama pada pembagian kursi tahap pertama, yaitu dengan membagi jumlah suara masuk yang diperoleh masing-masing peserta (partai atau daftar) dengan kuota atau harga sebuah kursi dalam suatu daerah pemilihan.

\section{Perbedaan}

Pemilu yang satu dengan Pemilu lainnya terdapat perbedaanperbedaan berkaitan dengan pengaturan dan penerapan sistem pemilu, termasuk variasi sistem atupun mekanisme pemilihannya. Unsur atau 
variabel sistem pemilihan yang berbeda pada setiap sistem pemilihan anggota DPR sejak Pemilu Masa Orde Lama sampai dengan Pemilu Masa Orde Reformasi, di antaranya adalah : jumlah atau besaran daerah pemilihan, besaran jumlah kursi nasional maupun jumlah kursi setiap daerah pemilihan, peserta, pencalonan dan penyusunan daftar calon, struktur surat suara dan cara pemberian suara, ada tidaknya penggabungan suara antar peserta, tata cara pembagian kursi sisa, dan tata cara penetapan calon terpilih.

Sistem pemilu anggota DPR yang satu dengan sistem pemilu angggota DPR lainnya sejak Masa Orde Lama sampai dengan Masa Orde Reformasi, walaupun secara tegas semuanya mencantumkan sistem pemilihan proporsional sebagai sistem dominannya, namun dalam beberapa unsur atau variabel sistem pemilihannya, terdapat pebedaan-perbedaan yang cukup tegas, terutama yang terkait dengan unsur electoral laws-nya, yaitu mengenai tata cara pembagian kursi sisa, tata cara penetapan calon terpilih, dan ada tidaknya penggabungan suara antar peserta.

Berikut akan akan digambarkan secara ringkas perbandingan pengaturan sistem pemilu Anggota DPR di Indonesia dengan menggunakan beberapa unsur atau variabel sistem pemilihan sebagai parameter perbandingannya, sebagaimana tabel berikut ini :

\section{Tabel 1. Perbandingan Pengaturan Sisitem Pemilu Anggota DPR di Indonesia}

\begin{tabular}{|c|c|c|c|c|c|}
\hline \multirow{3}{*}{$\begin{array}{l}\mathbf{N} \\
\text { o. }\end{array}$} & \multirow{3}{*}{ Parameter $^{16}$} & \multirow{2}{*}{$\begin{array}{c}\text { Pemilu Masa } \\
\text { Orde Lama } \\
\text { (Pemilu 1955) }\end{array}$} & \multirow{2}{*}{$\begin{array}{c}\text { Pemilu Masa } \\
\text { Orde Baru }\end{array}$} & \multicolumn{2}{|c|}{$\begin{array}{c}\text { Pemilu Masa Orde } \\
\text { Reformasi }\end{array}$} \\
\hline & & & & Pemilu 1999 & $\begin{array}{c}\text { Pemilu } \\
2004 \text { s/d } \\
\text { Pemilu } \\
2014\end{array}$ \\
\hline & & $\begin{array}{l}\text { UU No. } 7 \text { Th. } \\
1953\end{array}$ & $\begin{array}{l}\text { UU No. } 15 / 1969 \text {, } \\
\text { UU No. } 4 / 1975, \\
\text { UU No. } 2 / 1980, \\
\text { UU No. } 1 / 1985\end{array}$ & UU No. 3/1999 & $\begin{array}{l}\text { UU No. } 12 \\
\text { Th. 2003, } \\
\text { UU No. } 10 \\
\text { Th. } 2008 \text {, } \\
\text { UU No. } 8 \\
\text { Th. } 2012\end{array}$ \\
\hline \multicolumn{6}{|c|}{ Electoral Process } \\
\hline
\end{tabular}

16 Parameter perbandingan diolah dari unsur atau hal-hal yang terkait dengan sistem pemilihan umum sebagimana dikemukakan oleh Afan Gaffar, Moh. Mahfud MD, Muhammad Asfar, dan Arend Lijphart. 


\begin{tabular}{|c|c|c|c|c|c|}
\hline 1 & $\begin{array}{l}\text { Daerah } \\
\text { Pemilihan }\end{array}$ & $\begin{array}{l}\text { Ditetapkan } 16 \\
\text { daerah } \\
\text { pemilihan }\end{array}$ & $\begin{array}{l}\text { Ditetapkan } \\
\text { berdasarkan } \\
\text { wilayah provinsi }\end{array}$ & $\begin{array}{l}\text { Ditetapkan } \\
\text { berdasarkan } \\
\text { wilayah } \\
\text { provinsi }\end{array}$ & $\begin{array}{l}\text { Ditetapkan } \\
\text { berdasarka } \\
\mathrm{n} \text { wilayah } \\
\text { provinsi } \\
\text { atau } \\
\text { bagian- } \\
\text { bagian } \\
\text { provinsi }\end{array}$ \\
\hline 2 & $\begin{array}{l}\text { Jumlah } \\
\text { Kursi }\end{array}$ & $\begin{array}{l}\text { Ditetapkan } \\
\text { bedasarkan } \\
\text { pembagian } \\
\text { jumlah } \\
\text { penduduk } \\
\text { Indonesia } \\
\text { dengan angka } \\
300.000 \text { (tiga } \\
\text { ratus } \\
\text { ribu),setiap } \\
\text { dapil minimal } \\
3 \text { kursi }\end{array}$ & $\begin{array}{l}\text { Ditetapkan oleh } \\
\text { peraturan } \\
\text { perundang- } \\
\text { undangan (UU } \\
\text { Susduk); jumlah } \\
\text { kursi setiap dapil } \\
\text { minimal sama } \\
\text { dengan jumlah } \\
\text { daerah tingkat II }\end{array}$ & $\begin{array}{l}\text { Ditetapkan } \\
\text { oleh } \\
\text { peraturan } \\
\text { perundang- } \\
\text { undangan } \\
\text { (UU } \\
\text { Susduk); } \\
\text { setiap daerah } \\
\text { tingkat II } \\
\text { minimal } 1 \\
\text { kursi }\end{array}$ & $\begin{array}{l}\text { Ditetapkan } \\
\text { oleh } \\
\text { peraturan } \\
\text { perudang- } \\
\text { undangan } \\
\text { (UU } \\
\text { Pemilu); } \\
\text { jumlah } \\
\text { kursi setiap } \\
\text { dapil antara } \\
\text { 3-10 kursi, } \\
\text { kecuali } \\
\text { pemilu } \\
\text { 2004 antara } \\
\text { 3-12 kursi }\end{array}$ \\
\hline 3 & Peserta & $\begin{array}{l}\text { Perseorangan } \\
\text { dan Partai/ } \\
\text { golongan } \\
\text { Politik } \\
\text { (kumpulan) } \\
\text { dengan } \\
\text { mencantumka } \\
\text { n nama calon }\end{array}$ & $\begin{array}{l}\text { Golongan dan } \\
\text { Partai Politik }\end{array}$ & Partai Politik & $\begin{array}{l}\text { Partai } \\
\text { Politik } \\
\text { (sekaligus } \\
\text { calon- } \\
\text { calonnya) }\end{array}$ \\
\hline 4 & $\begin{array}{l}\text { Struktur } \\
\text { Surat } \\
\text { Suara dan } \\
\text { cara } \\
\text { pemberian } \\
\text { suara }\end{array}$ & $\begin{array}{l}\text { Berisikan } \\
\text { nomor, nama } \\
\text { dan gambar } \\
\text { daftar; serta } \\
\text { nomor dan } \\
\text { nama-nama } \\
\text { calon; } \\
\text { pemberian } \\
\text { suara dengan } \\
\text { memilih } \\
\text { daftar/ } \\
\text { memilih }\end{array}$ & $\begin{array}{l}\text { Berisikan nomor, } \\
\text { nama dan gambar } \\
\text { parpol; pemberian } \\
\text { suara dengan } \\
\text { memilih/mencobl } \\
\text { os parpol }\end{array}$ & $\begin{array}{l}\text { Berisikan } \\
\text { nomor, nama } \\
\text { dan gambar } \\
\text { parpol; } \\
\text { Pemberian } \\
\text { suara dengan } \\
\text { memilih } \\
\text { parpol }\end{array}$ & $\begin{array}{l}\text { Berisikan } \\
\text { nomor, } \\
\text { nama dan } \\
\text { gambar } \\
\text { parpol, } \\
\text { serta } \\
\text { nomor dan } \\
\text { nama-nama } \\
\text { calon; } \\
\text { pemberian } \\
\text { suara } \\
\text { dengan }\end{array}$ \\
\hline
\end{tabular}




\begin{tabular}{|c|c|c|c|c|c|}
\hline & & $\begin{array}{l}\text { calon/ } \\
\text { memilih daftar } \\
\text { dan calon } \\
\text { sekaligus }\end{array}$ & & & $\begin{array}{l}\text { memilih } \\
\text { parpol dan } \\
\text { calon } \\
\text { sekaligus/ } \\
\text { memilih } \\
\text { parpol } \\
\text { saja/memili } \\
\text { h calon saja } \\
\text { (khusus } \\
\text { Pemilu } \\
\text { 2009 dan } \\
\text { Pemilu } \\
\text { 2014) }\end{array}$ \\
\hline \multicolumn{6}{|c|}{ Electoral Laws } \\
\hline 5 & $\begin{array}{l}\text { Pembagian } \\
\text { Kursi } \\
\text { Pertama }\end{array}$ & $\begin{array}{l}\text { Bedasarkan } \\
\text { pembagian } \\
\text { jumlah suara } \\
\text { daftar dengan } \\
\text { BPP daerah } \\
\text { pemilihan }\end{array}$ & $\begin{array}{l}\text { Bedasarkan } \\
\text { pembagian jumlah } \\
\text { suara parpol (atau } \\
\text { gabungan parpol) } \\
\text { dengan BPP } \\
\text { daerah pemilihan }\end{array}$ & $\begin{array}{l}\text { Bedasarkan } \\
\text { pembagian } \\
\text { jumlah suara } \\
\text { parpol } \\
\text { dengan BPP } \\
\text { daerah } \\
\text { pemilihan }\end{array}$ & $\begin{array}{l}\text { Bedasarkan } \\
\text { pembagian } \\
\text { jumlah } \\
\text { suara } \\
\text { parpol } \\
\text { dengan } \\
\text { BPP daerah } \\
\text { pemilihan }\end{array}$ \\
\hline 6 & $\begin{array}{l}\text { Pembagian } \\
\text { Kursi Sisa }\end{array}$ & $\begin{array}{l}\text { Berdasarkan } \\
\text { pembagian } \\
\text { jumlah sisa } \\
\text { suara daftar di } \\
\text { seluruh } \\
\text { Indonesia } \\
\text { dengan BPP } \\
\text { kursi sisa; } \\
\text { Jika masih } \\
\text { terdapat kursi } \\
\text { sisa, dilakukan } \\
\text { pembagian } \\
\text { kursi } \\
\text { tambahan } \\
\text { berdasarkan } \\
\text { urutan sisa } \\
\text { suara } \\
\text { terbanyak } \\
\text { masing- }\end{array}$ & Tidak ada & $\begin{array}{l}\text { Berdasarkan } \\
\text { pembagian } \\
\text { jumlah sisa } \\
\text { suara parpol } \\
\text { atau } \\
\text { gabungan } \\
\text { parpol di } \\
\text { suatu daerah } \\
\text { pemilihan } \\
\text { dengan BPP } \\
\text { kursi sisa }\end{array}$ & $\begin{array}{l}\text { Berdasarka } \\
\text { n urutan } \\
\text { sisa suara } \\
\text { terbanyak } \\
\text { yang } \\
\text { diperoleh } \\
\text { setiap } \\
\text { parpol; atau } \\
\text { berdasarka } \\
\text { n sisa suara } \\
\text { parpol yang } \\
\text { mencapai } \\
\text { 50\% BPP - } \\
\text { dilanjutkan } \\
\text { sisa suara } \\
\text { parpol } \\
\text { dalam satu } \\
\text { propinsi } \\
\text { yang } \\
\text { mencapai }\end{array}$ \\
\hline
\end{tabular}




\begin{tabular}{|c|c|c|c|c|c|}
\hline & & masing daftar & & & $\begin{array}{l}\text { BPP baru } \\
\text { suatu } \\
\text { propinsi - } \\
\text { terakhir } \\
\text { berdasarka } \\
\text { n sisa suara } \\
\text { terbanyak } \\
\text { (khusus } \\
\text { Pemilu } \\
\text { 2009) }\end{array}$ \\
\hline 7 & $\begin{array}{l}\text { Penggabun } \\
\text { gan Suara }\end{array}$ & $\begin{array}{l}\text { Dilakukan } \\
\text { pada } \\
\text { pembagian } \\
\text { kursi pertama } \\
\text { dan } \\
\text { Pembagian } \\
\text { kursi sisa }\end{array}$ & $\begin{array}{l}\text { Dilakukan } \\
\text { sebelum } \\
\text { pembagian kursi } \\
\text { pertama }\end{array}$ & $\begin{array}{l}\text { Dimungkink } \\
\text { an pada } \\
\text { pembagian } \\
\text { kursi sisa, } \\
\text { keputusan } \\
\text { ada pada } \\
\text { KPU }\end{array}$ & Tidak ada \\
\hline 8 & $\begin{array}{l}\text { Penetapan } \\
\text { Calon } \\
\text { Terpilih }\end{array}$ & $\begin{array}{l}\text { Berdasarkan } \\
\text { jumlah suara } \\
\text { calon yang } \\
\text { mencapai } \\
\text { BPP; Calon } \\
\text { yang tidak } \\
\text { mencapai BPP } \\
\text { didasarkan } \\
\text { urutan calon } \\
\text { dalam daftar } \\
\text { calon (calon } \\
\text { yang } \\
\text { mencapai } \\
\text { seperdua BPP } \\
\text { didahulukan) }\end{array}$ & $\begin{array}{l}\text { Berdasarkan } \\
\text { urutan calon } \\
\text { dalam daftar } \\
\text { calon }\end{array}$ & $\begin{array}{l}\text { Berdasarkan } \\
\text { urutan suara } \\
\text { terbanyak } \\
\text { partai di } \\
\text { Daerah } \\
\text { Tingkat II } \\
\text { asal calon }\end{array}$ & $\begin{array}{l}\text { Berdasarka } \\
\text { n jumlah } \\
\text { suara calon } \\
\text { yang } \\
\text { mencapai } \\
\text { BPP; } \\
\text { Calon yang } \\
\text { tidak } \\
\text { mencapai } \\
\text { BPP, } \\
\text { penetapan } \\
\text { calon } \\
\text { terpilih } \\
\text { ditetapkan } \\
\text { berdasarka } \\
\text { n nomor } \\
\text { urut calon } \\
\text { dalam } \\
\text { daftar calon } \\
\text { (Pemilu } \\
\text { 2004 dan } \\
\text { Pemilu } \\
\text { 2009), dan } \\
\text { berdasarka } \\
\text { n perolehan } \\
\text { suara } \\
\text { terbanyak } \\
\text { calon }\end{array}$ \\
\hline
\end{tabular}




\begin{tabular}{|l|l|l|l|l|}
\hline & & & & (Pemilu \\
$2014)$
\end{tabular}

\section{Kelemahan dan Kelebihan Sistem Pemilu Anggota DPR di Indonesia}

Sampai saat ini belum ada yang secara tegas menyatakan atau memberikan pendapat tentang adanya sistem pemilihan umum yang secara absolut terbaik. Banyak ahli ilmu hukum maupun pakar ilmu politik berpendapat bahwa sistem pemilihan hanya dapat dikatakan terbaik jika dilihat dari konteks atau kondisi sosial, budaya, ekonomi dan politik sebuah negara. ${ }^{17}$ Artinya, baik-tidaknya suatu sistem pemilihan yang diterapkan pada sebuah negara bersifat relatif, tergantung dari kondisi kehidupan bermasyarakat dan negara yang bersangkutan. Dengan demikian dapat dikatakan bahwa setiap sistem pemilihan umum akan memiliki kelebihankelebihan sekaligus kelemahan-kelemahan ditinjau dari konteks atau sudut pandang yang berbeda-beda, tidak terkecuali pada sistem pemilihan proporsional representatif yang diatur dan diterapkan pada pemilu anggota DPR di Indonesia.

Sistem pemilihan proporsional representatif atau sistem perwakilan berimbang memiliki kelebihan atau keuntungan sekaligus kekurangan, yang oleh Miriam Budiardjo diuraikan sebagai berikut : ${ }^{18}$

\section{Kelebihan :}

a. Dianggap lebih representatif karena persentase perolehan suara setiap partai sesuai dengan persentase perolehan kursinya di parlemen, tidak ada distorsi antara perolehan suara dan perolehan kursi.

b. Setiap suara dihitung dan tidak ada yang hilang, partai kecil dan golongan minoritas diberi kesempatan untuk menempatkan wakilnya di parlemen, masyarakat yang heterogen dan pluralis lebih tertarik pada sistem ini.

\section{Kelemahan :}

a. kurang mendorong partai-partai untuk berintegrasi satu sama lain, malah sebaliknya cenderung mempertajam perbedaan di antara mereka.

\footnotetext{
${ }^{17} \mathrm{Hal}$ ini dapat diketahui dengan melihat hampir semua ilmuwan yang membahas tentang sistem pemilihan umum selalu menggambarkan adanya kelemahan dan kelebihan dari sistem pemilihan yang digunakan, walaupun kelemahan itu sangat kecil. Misalnya Moh. Mahfud MD dalam bukunya Politik Hukum di Indonesia, PT. RajaGrafindo ..., Op.Cit., p. 79-80, Miriam Budiardjo dalam bukunya Dasar-Dasar Ilmu Politik, Op.Cit., p. 466-471, dan Andrew Reynolds dalam tulisannya berjudul Merancang Sistem Pemilihan Umum, dimuat dalam Bakti, Ikrar Nusa dan Sihbudi, Riza (Editor). (2001). Menjauhi Demokrasi Kaum Penjahat, Bandung: Mizan, p. 115-122.

${ }^{18}$ Lihat Miriam Budiardjo, Op.Cit. p. 467-471, lihat juga Moh. Mahfud MD, Politik..., Pt. RajaGrafindo ..., Op.Cit., p. 79-80.
} 
Bertambahnya jumlah partai dapat menghambat proses integrasi di antara golongan di masyarakat yang sifatnya pluralis. Hal ini mempermudah fragmentasi dan berdirinya partai baru yang pluralis;

b. wakil rakyat kurang erat hubungannya dengan konstituennya, tetapi lebih erat dengan partainya. Peranan partai lebih menonjol daripada kepribadian seorang wakil rakyat;

c. banyaknya partai yang bersaing mempersukar satu partai untuk mencapai mayoritas di parlemen, hal ini mempersulit terbentuknya pemerintahan yang stabilkarena harus mendasarkan diri pada koalisi.

Dengan mendasarkan pada pendapat Miriam Budiardjo di atas, maka terhadap Sistem Pemilihan Umum Anggota DPR yang diterapkan pada Pemilu Masa Orde Lama sampai dengan Pemilu Masa Orde Reformasi, baik sistem proporsional tertutup maupun sistem proporsional terbuka dan sisa suara terbanyak, pada prinsipnya juga memiliki kelemahan sekaligus kelebihan.

Sistem proporsional tertutup yang diterapkan pada Pemilu Masa Orde Baru dan Pemilu 1999, dalam batas tertentu mempunyai kelemahan, di antaranya adalah pertanggungjawaban anggota DPR terhadap masyarakat atau konstituen sangat rendah dan partai politik lebih dominan daripada pemilih dalam menentukan calon terpilih, sementara kelebihannya adalah dalam segi pembiayaan menjadi sangat efisien dan lebih mudah atau lebih sederhana dalam penerapannya.

Sistem proporsional terbuka dan sisa suara terbanyak yang diterapkan pada Pemilu Masa Orde Lama dan Pemilu Masa Orde Reformasi pada Pemilu 2004 sampai dengan Pemilu 2014, dalam batas tertentu mempunyai kelemahan, di antaranya adalah adanya kemungkinan suara terbuang relatif besar, memunculkan partai-partai baru yang banyak, dan teknis pemungutan suaranya tidak efisien dan tidak praktis karena pemilih direpotkan dengan daftar nama calon yang panjang dan banyak, sementara kelebihannya adalah memberi kesempatan pemilih menentukan preferensinya kepada calon yang dikenalnya secara langsung, menurunkan fragmentasi partai pada pemilupemilu selanjutnya dengan tidak diperbolehkan penggabungan suara dan mendorong kerjasama antar partai mengingat cenderung partai-partai besar (partai pemenang) berkoalisi dalam menentukan pemerintahan

\section{Penutup}

Bardasarkan uraian tulisan di atas, dapat ditarik kesimpulan terkait dengan studi komparatif pengaturan sistem pemilihan umum anggota DPR di Indonesia, yaitu :

a. Perbandingan pengaturan sistem pemilihan umum anggota DPR di Indonesia pada Pemilu Masa Orde Lama sampai dengan Pemilu Masa Orde Reformasi, semua pengaturannya menerapkan sistem pemilihan 
yang sama yaitu sistem proporsional representatif, namun dengan variasi sistem yang berbeda. Sistem Pemilu Masa Orde Lama dan Masa Orde Reformasi (Pemilu 2004 s/d Pemilu 2014) menerapkan variasi sistem proporsional terbuka dan sisa suara terbanyak, sementara Sistem Pemilu Masa Orde Baru dan Pemilu 1999 menerapkan variasi sistem proporsional tertutup.

b. Setiap Sistem Pemilihan Umum Anggota DPR yang diterapkan pada Pemilu Masa Orde Lama sampai dengan Pemilu Masa Orde Reformasi, baik sistem proporsional tertutup maupun sistem proporsional terbuka dan sisa suara terbanyak, pada prinsipnya memiliki kelemahan sekaligus kelebihan. Sistem proporsional tertutup, kelemahannya adalah pertanggungjawaban anggota DPR terhadap masyarakat atau konstituen sangat rendah dan partai politik lebih dominan daripada pemilih dalam menentukan calon terpilih, sementara kelebihannya adalah dalam segi pembiayaan menjadi sangat efisien dan lebih mudah atau lebih sederhana dalam penerapannya. Sistem proporsional terbuka dan sisa suara terbanyak, kelemahannya adalah adanya kemungkinan suara terbuang relatif besar, memunculkan partai-partai baru yang banyak, dan teknis pemungutan suaranya tidak efisien dan tidak praktis, sementara kelebihannya adalah memberi kesempatan pemilih menentukan preferensinya kepada calon yang dikenalnya secara langsung, menurunkan fragmentasi partai pada pemilu-pemilu selanjutnya dengan tidak diperbolehkan penggabungan suara dan mendorong kerjasama antar partai mengingat cenderung partai-partai besar (partai pemenang) berkoalisi dalam menentukan pemerintahan.

\section{Daftar Pustaka}

\section{A. Buku}

Asfar, Muhammad (Editor). (2002). Model-Model Sistem Pemilihan Di Indonesia. Surabaya: Pusat Studi Demokrasi dan HAM dan Partnership for Governance Reform in Indonesia.

Asshiddiqie, Jimly. (2002). Konsolidasi Naskah UUD 1945 Setelah Perubahan Keempat. Jakarta: Pusat Studi HTN FH-UI.

Bhakti, Ikrar Nusa, dan Sihbudi, Riza (Editor). (2001). Menjauhi Demokrasi Kaum Penjahat. Bandung: Mizan.

Budiardjo, Miriam. (2013). Dasar-Dasar Ilmu Politik, Edisi Revisi Cetakan kesembilan. Jakarta: PT Gramedia Pustaka Utama.

Dermawan, Bernad Sutrisno. (2002). Konflik Politik Di KPU Dalam Pemilu 1999. Jakarta: PT. Mutiara Sumber Widya. 
Gaffar, Afan. (2000). Politik Indonesia Transisi Menuju Demokrasi, Cetakan II. Yogyakarta: Pustaka Pelajar.

Lijphart, Arend. (1999). Patterns of Democracy, Yale University Press.

Mahfud MD, Moh. (1999). Hukum dan Pilar-Pilar Demokrasi. Yogyakarta: Gama Media. . (1998). Politik Hukum Di Indonesia. Jakarta: LP3ES. (2012). Politik Hukum di Indonesia, Cetakan ke-5. Jakarta: PT RajaGrafindo Persada.

Maksudi, Beddy Iriawan. (2012). Sistem Politik Indonesia, Pemahaman Secara Teoritik dan Empirik, Cetakan ke-2. Jakarta: PT RajaGrafindo Persada.

Samego, Indria, dkk. (1998). Menata Negara Usulan LIPI Tentang RUU Politik. Bandung: Mizan.

\section{B. Peraturan Perundang-Undangan}

Kitab Undang-undang Hukum Perdata. (KUHP perdata).

Undang-Undang Nomor 5 tahun 1999 tentang Larangan Praktik Monopoli.

Keputusan Presiden Nomor 75 tahun 1999 tentang pengukuhan KPPU (Komisi Pengawas Persaingan Usaha).

Peraturan Menteri Perdagangan No. 11/M-DAG/PER/3/20.

\section{Sumber Lain}

Asshiddiqie, Jimly. (2003). "Hubungan Kerja Antara DPD Dengan Lembaga Negara Lainnya". Makalah. Malang.

Dhakidae, Daniel. (1981). "Pemilihan Umum Di Indonesia: Saksi Pasang Naik dan Surut Partai Politik". majalah Prisma edisi September 1981 Tahun X, LP3ES, Jakarta.

Gaffar, Afan. (1989). "Sistem Pemilihan Umum di Indonesia: Beberapa Catatan Kritis", dalam Majalah Unisia Edisi No. 6 Tahun X Triwulan III.

Sejarah Pemilu yang dimuat oleh KPU, diperoleh melalui website www.kpu.go.id. 